\title{
NEMVEZETŐ KORROZIÓVÉDỎ BEVONATOK VIZSGÁLATA SZÁMÍTÓGÉPPEL TÁMOGATOTT ELEKTROKÉMIAI MÓDSZERREL
}

Gál Sémer Sándor

\section{Összefoglalás}

A korszeñ́ technikai fejlesztésben, energiatermelésben és kơrnyezetvédelemben a korrózió egy jelentős korlátozó tényezót jelent, ugyanis az országok bruttó nemzeti ossztermékének 3-4\%-át a korrózió okozta károk emésztik fel. $\mathrm{Az}$ irodalmi utalásokból látszik, hogy a korrózió lassanként napi témává válik [1]. Célunk egy laboratóriumi illetve ipari körülmények kőzőtt is alkalmazható múanyag bevonatok jóságának vizsgálatára alkalmas számítógéppel támogatott mérôrendszer kialakítása volt. A mérés alapja a bevonat ellenállásának mérése a bevonat felületén. A mérőrendszer egy számítógépből, mérőkártyából, elektródamozgató rendszerből és munkaelektródból áll. A kiépitett hardvert az általunk kifejlesztett szoftver vezérli.

Adatfeldolgozó szoftverünket mérési adatok alapján generált adatokon teszteltük és az elvégzett statisztikai vizsgálatok eredményei alapján állíthatjuk, hogy módszerünk alkalmas a bevonatok jóságának vizsgálatára, és a kiépített szoftver jelentôs segitséget nyújt a bevonatok minőségének kiértékelésében.

Fojlesztési tervek:

- Az oszlopdiagrammok térhálós ábrákkal tơrténő helyettesítése.

- Tizenkét bites A/D átalakító alkalmazása a mérés pontosságának nővelésére.

- A mérő̃rendszer alkalmazása görbült felületek vizsgálatára.

\section{Kisérleti módszer}

Tanszékünkoon a korróziót elektrokémiai módszerekkel vizsgáltuk. Mivel nemvezető korrózióvédó bevonatok vizsgálatáról volt szó, nem alkalmazhattuk a vonatkozó szakirodalomban javasolt voltammetriás módszereket a hidrogén adszorpció sebességi állandojának meghatározására, vagy nem vizsgálhattuk a korróziós inhibitorok hatását a Tafel meredekségre, mivel ezen esetekben a beoldódás jelenségével kellett volna számolnunk, a mi feladatunk pedig éppen a bevonat porózusságának vizsgálata volt.

Megállapitottuk, hogy a mủanyag bevonatok jóságának vizsgálatára az ellenállás mérése a legalkalmasabb [2]. Az erre vonatkozó szakirodalmi utalások szerint a polarizációs gơrbe alakját jelentősen 
befolyásolja a két elektród kơzőtti ellenállás. Ennek mérésére intézetünkben egy kisérleti berendezést fejlesztettünk ki. A méröberendezés tơbb fejlesztési változaton esett át:

- Az első változatnál egy referens elektród alkalmazásával, kételektródos rendszerben mérték a kialakult galvánelem polarizációs áramát, és egy vonal mentén jellemezni tudták a bevonat minőségét.

- A második változat egy Commodore 64-es számitógépet használt fel adatgyưjtésre. A számítógépet egy AD átalakító segítségével csatolták a méröberendezéshez. A módszer lényege a kővetkező volt: a vizsgálandó felületre egy müanyag keretet ragasztottak, a felületet elárasztották elektrolittal, ebbe merült a klórozott ezust elektród. Ezzel a változattal immár x-y irányban jellemezni tudták a bevonat jóságát. A módszer hátránya, hogy a lemez-elektród távolság növelésével nö az elektród hatósugara, és csőkken a felbontóképesség. Adott elektród-lemez távolság esetén nem nővelhetỏ a mérési pontok száma egy adott vonal mentén, mert a mért adatok nem lesznek függetlenek egymástól.

- E hiány pótlására fejlesztettük ki a harmadik változatot, mely még csak kísérleti fázisban van. Ennek lényege, hogy az elektrolitot egy kapillárison keresztül löjük az elektródra, ezáltal az elektród hatássugara $1 \mathrm{~mm}$ körüli értékekre csőkken. További előny, hogy e berendezés nemcsak vízszintes felületek vizsgálatára lesz alkalmas, hanem ha megoldjuk a felfogását, akkor függöleges falak, mennyezet vizsgálatára, sỏt akár gơrbült felületek vizsgálatára is alkalmassá tehetö. A módszer felbontóképessége jelentősen megnött, az elektród csőkkent hatássugarának köszőnhetően.

A mérörendszer fejlesztésénél ki kellett választani a géptípust, a mérőkártyát illetve a programozási nyelvet.

- Napjainkban a 16 bites, 32 bites számítógépek, elsősorban IBM PC - k, illetve az ezzel kompatibilis típusok elterjedésćnek lehetünk tanúi. Ugyan más típusú gépek is kaphatók, melyek néhány jellemzöje jobb, mint az IBM PC-é, de mind szoftver ellátottságban, mind árban egyértelmüen a PC-k az alkalmasabbak. Mérésre, vezérlésre illetve a mért adatok kiértékelésére egy IBM-AT 486-os számitógépet használtunk.

- A kémiai mérések elvégzéséhez a számítógépbe bővítő kártyát kell illeszteni [3]. Sokféle bơvitő kártya létezik. A leggyakrabban használt kártyák jellemzö paramétereit az 1. táblázat foglalja ơssze:

1.Táblázat: Mérökártvák jellemzô paramétereinek ósszehasonlítása

\begin{tabular}{|c|c|c|c|c|}
\hline $\begin{array}{r}\text { Kártya } \\
\text { tipus }\end{array}$ & PCL-711 & DAS-50 & DAS-40 & DAS-HRES \\
\hline Jellemzök & $40 \mathrm{kHz}$ & $1000 \mathrm{kHz}$ & $250 \mathrm{kHz}$ & $47.6 \mathrm{kHz}$ \\
\hline Frekvencia & $12 \mathrm{bit}$ & $12 \mathrm{bit}$ & $12 \mathrm{bit}$ & $16 \mathrm{bit}$ \\
\hline $\begin{array}{c}\text { Mérhelbontás feszültség } \\
\text { tartomány }\end{array}$ & $\pm 5 \mathrm{~V}$ & $\begin{array}{c}0+5 \mathrm{~V}, \\
0+10 \mathrm{~V}, \pm 5 \mathrm{~V}\end{array}$ & $\begin{array}{c}0+10 \mathrm{~V} \pm 5 \mathrm{~V}, \\
\pm 10 \mathrm{~V}\end{array}$ & $\begin{array}{c}0+5 \mathrm{~V}, \\
0+10 \mathrm{~V}, \pm 5 \mathrm{~V},\end{array}$ \\
\hline Analóg bemenet & 8 & 4 & $8 / 16$ & 8 \\
\hline Analóg kimenet & 1 & - & 2 & 2 \\
\hline Digitális bemenet & 16 & - & 16 & 8 \\
\hline Digitális kimenet & 16 & - & 16 & 8 \\
\hline Hiba & $0.015 \% \pm 1$ bit & $\pm 0.03 \%$ & $\pm 0.03 \%$ & $0.03 \% \pm 1 \mathrm{bit}$ \\
\hline
\end{tabular}


Az emlitett kártyák ára a paramétereik fuuggvényében változik. A méréseinkhez a PCL-711S kártyát választottuk.

- Az analitikai alkalmazásokhoz nem elegendő a számitógép, hanem megfelelö szoftverekre és interfészekre van szükség. A konkrét analitikai meghatározásokra, a méréstipusok speciális igényeinek megfelelő rendszereket kell kifejlesteni. Mivel a Windows erösen támogatja a grafikák, a képernyőablakok kezelését és sok más hasznos lehetőséggel is rendelkezik úgy dơntőttünk, hogy a mérőrendszert Windows operációs rendszerben fog mükơdni. Figyelembe véve a nagy adatmennyiséget a gyors, korszerü adatkiértékelés érdekében célszerü volt egy a saját céljainknak megfelelö szoftvert fejleszteni. A program segitségével vezéreljük az adatgyüjtőt és a mérés befejezése után gyors, az elemzés szempontjainak megfelelő, a vizsgált bevonat minősitését elősegitő jelentés készittetünk. Nem zárkoztunk el a statisztikai szoftverek (pl. Systat) használatának lehetőségétől sem. A szoftver adatait a Systat, Excel vagy más szoftver is elfogadja. A kidolgozott szoftver Borland Pascal for Windows 7.0 programozói kơzeggel készült.

\section{A feliiletelemzö szoftver ismertetése}

Mivel a kisérleti berendezés még fejlesztés alatt van, ezért az eddigi kisérleti adatok alapján generált adatokkal dolgoztunk. Kvázi, három dimenziós forgatható ábrák segitségével a felület térben megjelenithető. A jobb szemléltetés érdekében a mérési értékekhez szinámyalatokat rendeltünk hozzá. Az AD átalakító által a 0-1V-ig teijedó jelre 0-255 közotti digit értékeket kapunk. A 0-hoz zőld szint rendeltünk hozzá, a 255-höz pirosat. A kettő közőtti értékeknek a nagyságuk függvényében kikevert szinárnyalat felel meg (Az előző mérések Commodore 64 számitógéppel tơrténtek, melyhez egy tizenhat csatornás 8 bites A/D átalakitón keresztül csatlakoztatták a mérörendszert, ennek kőszőnhető a kis felbontás). Az elektródot $\mathrm{x}$ irányban egy léptetómotor mozgatta, a sor letapogatása után egy másik léptetőmotor segitségével az elektródot y irányban elmozditva újabb sor elemzése végezhető el. A letapogatás sürüségét az elektród hatássugarának figyelembevételével a szoftver segitségével beállithajuk.

A felülnézeti ábrajól szemlélteti a felület hibáit. Adott sor az egér segitségével kijelollhetö, és külơn is ábrázolható és kiértékelhetö (1. ábra).

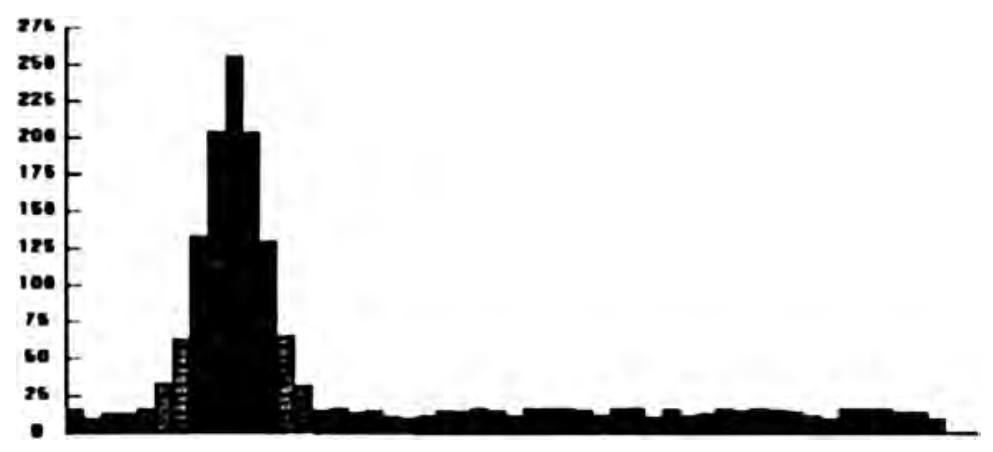

1. Ábra: 11. y-sor metszete 
Az adatok elemzése után általános jelentést készíttethetünk, mely magába fogja foglalni a lemez méreteit, a mérési átlagot, a szórást, az adatok eloszlását $\mathrm{X}_{\mathrm{k}} \pm 3 \mathrm{~S}$ tartományban, majd mindezt megkapjuk soronkénti felbontásban is. Ebben az esetben a hibahelyeknek megfelelö értékeket kiugorjuk. Ezek után megkapjuk a hibák soronkénti százalékos eloszlását, értékét, eltérését az átlagtól, és a lemezen elfoglalt helyük koordinátáit. A jelentés rơvidített változatát a 2.táblázat szemlélteti. A metszet elkészittetésével a csúcsról külơn jelentést is készittethetünk, ugyanis a csúcs interpolálásra spline függvényt alkalmaztunk. Az eljárás a spline-ot harmadfokú polinom darabokból rakja ơssze, oly módon, hogy az elsỏ és másod rendủ derivált folytonos, az illesztett görbe pedig a legsimább legyen. A spline-ot felhasználva a csúcs alatti terület kiintegrálható, és belőle mennyiségi kơvetkeztetéseket lehet levonni a hibahely nagyságára vonatkozóan (3. táblázat).

\section{Táblázat: Általános jelentés}

\begin{tabular}{|c|c|c|}
\hline \multicolumn{3}{|c|}{ A vizsgált védőréteg jellemzöi } \\
\hline Szélesség (x) [mm] & & ság (y) [mm] \\
\hline 100 & & 120 \\
\hline \multicolumn{3}{|c|}{ A teljes felületre vonatkoztatott (hibákat leszámítva): } \\
\hline Atlag & Szórás & Eloszlás $\left(\mathrm{X}_{\mathrm{k}}+3 \mathrm{~S}\right)[\%]$ \\
\hline 13.475 & 2.2834 & 100 \\
\hline \multicolumn{3}{|c|}{ Hibaszázalék (\%) } \\
\hline \multicolumn{2}{|l|}{ Teljes felületre } & 4.24 \\
\hline \multicolumn{2}{|l|}{ 11. sor } & 18 \\
\hline \multicolumn{2}{|l|}{ 36. sor } & 10 \\
\hline
\end{tabular}

\section{Táblázat: Metszetek}

Spline függvénnyel számitott csúcs alatti terület (digit*mm)

\begin{tabular}{l|c} 
11. sor & 240 \\
\hline 36. sor & 90
\end{tabular}

A mérési adatok függetlenségvizsgálatát [4] külơnféle ábrázolásmódok segítségével vizsgáltuk, korróziós hibahelyet nem tartalmazo, illetve tartalmazó adatsorok esetében

\section{Irodalom}

[1.] TAGESZEITUING FÜR BRAUEREI, 85, 12, 1985

[2.] RÓNAY D.: A felualeti áram- és potenciáleloszlás vizsgálata galvánelektródos rendszerben Magy. Kém. Lapja (40) 8, 327-332, (1985)

[3.] HȦZI J., DARUHȦZI L., PINTÉR Ö., HAGY F.: IBM PC kompatibilis számítógépek analitikai alkalmazásának lehetōségei - Magy. Kém. Folyóirat (94) 5, 198-203, (1988)

[4.] BUJTÁS P. - LEISZTNER L.: Analitikai mérési eredmények minőségbiztositása - Budapest, GLP Kft, 1991

\section{Gál Sémer Sándor}

\section{MISKOLCI EGYETEM, Fizikai-Kémiai Tanszék}

H-3515 Miskolc-Egyetemváros, Fax: 0036-46-311140, E-mail: fkmgal@gold.uni-miskolc.hu 